\title{
Synthesis and Styrene Copolymerization of Novel Chloro and Fluoro Ring-Trisubstituted Propyl Cyanophenylpropenoates
}

\author{
Jessica Bates ${ }^{1}$, Ashleigh L. Krider ${ }^{1}$, Sana A. Malik ${ }^{1}$, Denny P. May ${ }^{1}$, Maryana Stryelkina ${ }^{1}$, Chloe G. Williams ${ }^{1}$, Daniel T. \\ Wood $^{1}$, Sara M. Rocus ${ }^{1}$, Gregory B. Kharas ${ }^{1}$ \\ ${ }^{1}$ Chemistry Department, DePaul University, Chicago, USA \\ Correspondence: Gregory B. Kharas, Chemistry Department, DePaul University, 1110 West Belden Avenue, Chicago, \\ IL 60614-3214, USA. Tel: 1-773-325-7367. E-mail: gkharas@ depaul.edu
}

Received: March 5, 2019 Accepted: April 14, 2019 Online Published: April 15, 2019

doi:10.5539/ijc.v11n1p79 URL: https://doi.org/10.5539/ijc.v11n1p79

\begin{abstract}
Novel trisubstituted ethylenes, ring-substituted propyl 2-cyano-3-phenyl-2-propenoates, $\mathrm{RPhCH}=\mathrm{C}(\mathrm{CN}) \mathrm{CO}_{2} \mathrm{C}_{3} \mathrm{H}_{7}$ (where $\mathrm{R}$ is 2,3,6-trichloro, 2,3,4-trifluoro, 2,3,5-trifluoro, 2,4,5-trifluoro, 2,4,6-trifluoro, 3,4,5-trifluoro) were prepared by the piperidine catalyzed Knoevenagel condensation of ring-trisubstituted benzaldehydes and propyl cyanoacetate.

The ethylenes when copolymerized with styrene in solution with radical initiation $(\mathrm{ABCN})$ at $70^{\circ} \mathrm{C}$ resulted in formation of copolymers. The composition of the copolymers was calculated from nitrogen analysis. The structures and properties were characterized by IR, ${ }^{1} \mathrm{H}$ and ${ }^{13} \mathrm{C}-\mathrm{NMR}$, GPC, DSC, and TGA.
\end{abstract}

Keywords: radical copolymerization; styrene copolymers; trisubstituted ethylenes

\section{Introduction}

Ring-functionalized trisubstituted ethylenes (TSE), esters of 2-cyano-3-phenyl-2-propenoic acid, $\mathrm{R}^{1} \mathrm{PhCH}=\mathrm{C}(\mathrm{CN}) \mathrm{CO}_{2} \mathrm{R}^{2}$ continue to attract attention as compounds with interesting properties and as comonomers for modification of commercial polymers. Thus, dimethylamino ring-substituted methyl 2-cyano-3-phenyl-2-propenoate was examined among other cyanovinylheteroaromatics in relation to organic nonlinear optics (Matsuoka et al., 1990). Applications of ethyl 2-cyano-3-phenyl-2-propenoate, ECPP and its ring-substituted derivatives include studies of antifungal potential (Sidhu et al., 2008) and antileishmanial activity (Tiwari et al., 1999). 2-Fluorophenyl substituted ECPP was used in studies of estrogen receptor dependent inhibitors (Caggiano et al., 2007).

It was shown that electrophilic tri- and tetrasubstituted olefins are particularly useful in delineating the transition from radical chemistry to ionic chemistry (Hall \& Padias 2004).

In regard to polymerization reactivity, previous studies showed that TSE containing substituents larger than fluorine have very low reactivity in radical homopolymerization due to polar and steric reasons. Although steric difficulties preclude homopolymerization of most TSE monomers, their copolymerization with a monosubstituted alkene makes it possible to overcome these steric problems (Odian 2004). Copolymerization of electrophilic TSE having double bonds substituted with halo, cyano, and carbonyl groups and electron-rich monosubstituted ethylenes such as styrene, $N$-vinylcarbazole, and vinyl acetate (Hall \& Daly 1975, Hall \& Ikman 1977, Kharas 1996) show a tendency toward the formation of alternating copolymers - thus suggesting a way of functionalization of commercial polymers via introduction of isolated TSE monomer units.

Similarly ring-substituted TSE monomers, 3-phenyl-2-dicyanoethenes (Kharas 2011) and butyl 3-phenyl-2-cyano-2-propenoates (Kharas 2016) were copolymerized with 4-flourostyrene and styrene, respectively. With the objective to design novel structures, that could serve as a spring board for further development of novel materials with new properties and applications, and in continuation of our studies of the monomer structure-reactivity correlation in the radical copolymerization of TSE monomers we have prepared ring-trisubstituted propyl 2-cyano-3-phenyl-2-propenoates (PCPP), $\mathrm{RPhCH}=\mathrm{C}(\mathrm{CN}) \mathrm{CO}_{2} \mathrm{C}_{3} \mathrm{H}_{7}$, where $\mathrm{R}$ is 2,3,6-trichloro, 2,3,4-trifluoro, 2,3,5-trifluoro, 2,4,5-trifluoro, 2,4,6-trifluoro, 3,4,5-trifluoro, and explore the feasibility of their copolymerization with styrene. To the best of our knowledge, there have been no reports on either synthesis of these propyl 2-cyano-3-phenyl-2-propenoates, nor their copolymerization with styrene. 


\section{Experimental}

2,3,6-Trichloro, 2,3,4-trifluoro, 2,3,5-trifluoro, 2,4,5-trifluoro, 2,4,6-trifluoro, 3,4,5-trifluoro, propyl cyanoacetate, piperidine, styrene, 1,1'-azobiscyclohexanecarbonitrile, $(\mathrm{ABCN})$, and toluene supplied from Sigma-Aldrich Co., were used as received.

Infrared spectra of the TSE monomers and polymers ( $\mathrm{NaCl}$ plates) were determined with an ABB FTLA 2000 FT-IR spectrometer. The melting points of the monomers, the glass transition temperatures $\left(T_{\mathrm{g}}\right)$, of the copolymers were measured with TA (Thermal Analysis, Inc.) Model Q10 differential scanning calorimeter (DSC). The thermal scans were performed in a 25 to $200^{\circ} \mathrm{C}$ range at heating rate of $10^{\circ} \mathrm{C} / \mathrm{min}$. $T_{\mathrm{g}}$ was taken as a midpoint of a straight line between the inflection of the peak's onset and endpoint. The thermal stability of the copolymers was measured by thermogravimetric analyzer (TGA) TA Model Q50 from ambient temperature to $800^{\circ} \mathrm{C}$ at $20^{\circ} \mathrm{C} / \mathrm{min}$. The molecular weights of the polymers was determined relative to polystyrene standards in THF solutions with sample concentrations $0.8 \%(\mathrm{w} / \mathrm{v}$ ) by gel permeation chromatography (GPC) using a Altech $426 \mathrm{HPLC}$ pump at an elution rate of $1.0 \mathrm{~mL} / \mathrm{min}$; Phenogel $5 \mu$ Linear column at $25^{\circ} \mathrm{C}$ and Viscotek 302 detector. ${ }^{1} \mathrm{H}$ - and ${ }^{13} \mathrm{C}$-NMR spectra were obtained on $10-25 \%$ $(\mathrm{w} / \mathrm{v})$ monomer or polymer solutions in $\mathrm{CDCl}_{3}$ at ambient temperature using Avance $300 \mathrm{MHz}$ spectrometer. Elemental analyses were performed by Midwest Microlab, LLC (IN).

\section{Results and discussion}

\subsection{Synthesis of Monomers}

The ring-trisubstituted propyl 2-cyano-3-phenyl-2-propenoates (PCPP) were synthesized by Knoevenagel condensation (Smith \& March 2001) of a ring-trisubstituted benzaldehyde with propyl cyanoacetate, catalyzed by base, piperidine.
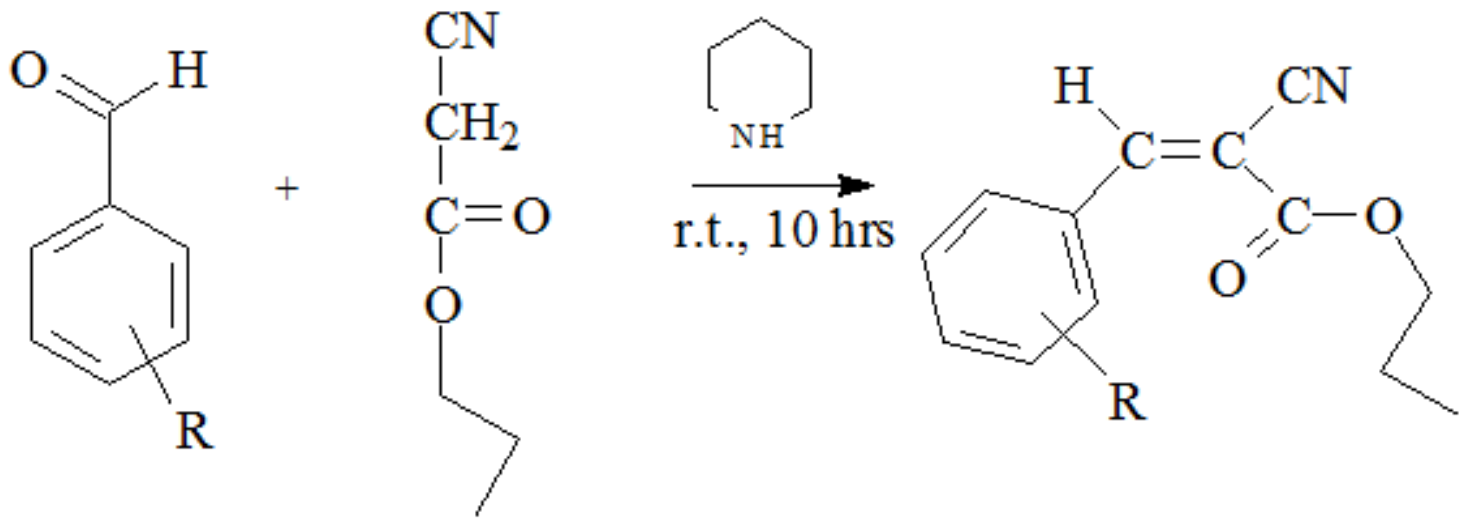

Scheme 1. Synthesis of propyl 2-cyano-3-phenyl-2-propenoates $\mathrm{RPhCH}=\mathrm{C}(\mathrm{CN}) \mathrm{CO}_{2} \mathrm{C}_{3} \mathrm{H}_{7}$

where $\mathrm{R}$ is 2,3,6-trichloro, 2,3,4-trifluoro, 2,3,5-trifluoro, 2,4,5-trifluoro, 2,4,6-trifluoro, 3,4,5-trifluoro.

The procedure was essentially the same for all the monomers. In a typical synthesis, equimolar amounts of propyl cyanoacetate and an appropriate ring-trisubstituted substituted benzaldehyde were mixed in equimolar ratio in a $20 \mathrm{~mL}$ vial. A few drops of piperidine were added with stirring. The product of the reaction was isolated by filtration and purified by crystallization from 2-propanol. The condensation reaction proceeded smoothly, yielding products, which were purified by conventional techniques.

\subsubsection{Propyl 2-cyano-3-(2,3,6-trichlorophenyl)-2-propenoate}

Yield 83\%; ${ }^{1} \mathrm{H}-\mathrm{NMR} \delta 8.5(\mathrm{~s}, 1 \mathrm{H}, \mathrm{CH}=), 8.1-7.0(\mathrm{~m}, 2 \mathrm{H}, \mathrm{Ph}), 4.3\left(\mathrm{t}, 2 \mathrm{H}, \mathrm{OCH}_{2}\right), 1.7\left(\mathrm{~m}, 2 \mathrm{H}, \mathrm{OCH}_{2} \mathrm{CH}_{2}\right), 1.0(\mathrm{t}, 3 \mathrm{H}$, $\left.\mathrm{OCH}_{2} \mathrm{CH}_{2} \mathrm{CH}_{3}\right) ;{ }^{13} \mathrm{C}-\mathrm{NMR} \delta 163(\mathrm{C}=\mathrm{O}), 152(\mathrm{HC}=), 133,131,130(\mathrm{Ph}), 116(\mathrm{CN}), 114(\mathrm{C}=), 67\left(\mathrm{OCH}_{2}\right), 22$ $\left(\mathrm{OCH}_{2} \mathrm{CH}_{2}\right), 10\left(\mathrm{OCH}_{2} \mathrm{CH}_{2} \mathrm{CH}_{3}\right)$; IR $\left(\mathrm{cm}^{-1}\right): 3120-2828(\mathrm{~m}, \mathrm{C}-\mathrm{H}), 2222(\mathrm{~m}, \mathrm{CN}), 1723(\mathrm{~s}, \mathrm{C}=\mathrm{O}), 1561(\mathrm{~s}, \mathrm{C}=\mathrm{C}), 1262(\mathrm{~s}$, C-O-C), 832 (s, C-H out of plane). Anal. Calcd. for $\mathrm{C}_{13} \mathrm{H}_{10} \mathrm{Cl}_{3} \mathrm{NO}_{2}$ : C, 49.01; H, 3.16; N, 4.40; Found: C, 49.45; H, 3.19; $\mathrm{N}, 4.58$.

\subsubsection{Propyl 2-cyano-3-(2,3,4-trifluorophenyl)-2-propenoate}

Yield 74\%; mp 51 ${ }^{\circ} \mathrm{C},{ }^{1} \mathrm{H}-\mathrm{NMR} \delta 8.5(\mathrm{~s}, 1 \mathrm{H}, \mathrm{CH}=), 8.2-7.0(\mathrm{~m}, 2 \mathrm{H}, \mathrm{Ph}), 4.3\left(\mathrm{t}, 2 \mathrm{H}, \mathrm{OCH}_{2}\right), 1.7\left(\mathrm{~m}, 2 \mathrm{H}, \mathrm{OCH}_{2} \mathrm{CH}_{2}\right), 1.0$ (t, 3H, OCH $\left.\mathrm{CH}_{2} \mathrm{CH}_{3}\right) ;{ }^{13} \mathrm{C}-\mathrm{NMR} \delta 163(\mathrm{C}=\mathrm{O}), 152(\mathrm{HC}=), 142,114,111(\mathrm{Ph}), 116(\mathrm{CN}), 102(\mathrm{C}=), 67\left(\mathrm{OCH}_{2}\right), 22$ $\left(\mathrm{OCH}_{2} \mathrm{CH}_{2}\right), 10\left(\mathrm{OCH}_{2} \mathrm{CH}_{2} \mathrm{CH}_{3}\right)$; IR $\left(\mathrm{cm}^{-1}\right): 3150-2825(\mathrm{~m}, \mathrm{C}-\mathrm{H}), 2228(\mathrm{~m}, \mathrm{CN}), 1715(\mathrm{~s}, \mathrm{C}=\mathrm{O}), 1624(\mathrm{~s}, \mathrm{C}=\mathrm{C}), 1262(\mathrm{~s}$, C-O-C), 828 (s, C-H out of plane). Anal. Calcd. for $\mathrm{C}_{13} \mathrm{H}_{10} \mathrm{~F}_{3} \mathrm{NO}_{2}$ : C, 58.00; H, 3.74; N, 5.20; Found: C, 57.83; H, 3.76; N, 5.45 . 


\subsubsection{Propyl 2-cyano-3-(2,3,5-trifluorophenyl)-2-propenoate}

Yield 92\%; ${ }^{1} \mathrm{H}-\mathrm{NMR} \delta 8.4(\mathrm{~s}, 1 \mathrm{H}, \mathrm{CH}=), 7.9-7.0(\mathrm{~m}, 2 \mathrm{H}, \mathrm{Ph}), 4.3\left(\mathrm{t}, 2 \mathrm{H}, \mathrm{OCH}_{2}\right), 1.7\left(\mathrm{~m}, 2 \mathrm{H}, \mathrm{OCH}_{2} \mathrm{CH}_{2}\right), 1.0(\mathrm{t}, 3 \mathrm{H}$, $\left.\mathrm{OCH}_{2} \mathrm{CH}_{2} \mathrm{CH}_{3}\right) ;{ }^{13} \mathrm{C}-\mathrm{NMR} \delta 163(\mathrm{C}=\mathrm{O}), 152(\mathrm{HC}=), 159,150,123,121(\mathrm{Ph}), 116(\mathrm{CN}), 104(\mathrm{C}=), 67\left(\mathrm{OCH}_{2}\right), 22$ $\left(\mathrm{OCH}_{2} \mathrm{CH}_{2}\right), 10\left(\mathrm{OCH}_{2} \mathrm{CH}_{2} \mathrm{CH}_{3}\right)$; IR $\left(\mathrm{cm}^{-1}\right): 3120-2820(\mathrm{~m}, \mathrm{C}-\mathrm{H}), 2229(\mathrm{~m}, \mathrm{CN}), 1740(\mathrm{~s}, \mathrm{C}=\mathrm{O}), 1608(\mathrm{~s}, \mathrm{C}=\mathrm{C}), 1281(\mathrm{~s}$, C-O-C), 862, 803 (s, C-H out of plane). Anal. Calcd. for $\mathrm{C}_{13} \mathrm{H}_{10} \mathrm{~F}_{3} \mathrm{NO}_{2}$ : C, 58.00; H, 3.74; N, 5.20; Found: C, 57.83; H, $3.79 ; \mathrm{N}, 5.16$.

\subsubsection{Propyl 2-cyano-3-(2,4,5-trifluorophenyl)-2-propenoate}

Yield 89\%; ${ }^{1} \mathrm{H}-\mathrm{NMR} \delta 8.2(\mathrm{~s}, 1 \mathrm{H}, \mathrm{CH}=), 7.7-7.0(\mathrm{~m}, 2 \mathrm{H}, \mathrm{Ph}), 4.4\left(\mathrm{t}, 2 \mathrm{H}, \mathrm{OCH}_{2}\right), 1.7\left(\mathrm{~m}, 2 \mathrm{H}, \mathrm{OCH}_{2} \mathrm{CH}_{2}\right), 1.0(\mathrm{t}, 3 \mathrm{H}$, $\left.\mathrm{OCH}_{2} \mathrm{CH}_{2} \mathrm{CH}_{3}\right) ;{ }^{13} \mathrm{C}-\mathrm{NMR} \delta 163(\mathrm{C}=\mathrm{O}), 152(\mathrm{HC}=), 151,146,118,105(\mathrm{Ph}), 116(\mathrm{CN}), 102(\mathrm{C}=), 67\left(\mathrm{OCH}_{2}\right), 22$ $\left(\mathrm{OCH}_{2} \mathrm{CH}_{2}\right), 10\left(\mathrm{OCH}_{2} \mathrm{CH}_{2} \mathrm{CH}_{3}\right)$; IR $\left(\mathrm{cm}^{-1}\right): 3100-2820(\mathrm{~m}, \mathrm{C}-\mathrm{H}), 2229(\mathrm{~m}, \mathrm{CN}), 1731(\mathrm{~s}, \mathrm{C}=\mathrm{O}), 1621(\mathrm{~s}, \mathrm{C}=\mathrm{C}), 1258$ (s, C-O-C), 825 (s, C-H out of plane). Anal. Calcd. for $\mathrm{C}_{13} \mathrm{H}_{10} \mathrm{~F}_{3} \mathrm{NO}_{2}$ : C, 58.00; H, 3.74; N, 5.12; Found: C, 57.16; H, 3.86; N, 5.26.

\subsubsection{Propyl 2-cyano-3-(2,4,6-trifluorophenyl)-2-propenoate}

Yield $82 \%$; ${ }^{1} \mathrm{H}-\mathrm{NMR} \delta 8.2(\mathrm{~s}, 1 \mathrm{H}, \mathrm{CH}=), 7.0-6.6(\mathrm{~m}, 2 \mathrm{H}, \mathrm{Ph}), 4.3\left(\mathrm{t}, 2 \mathrm{H}, \mathrm{OCH}_{2}\right), 1.7\left(\mathrm{~m}, 2 \mathrm{H}, \mathrm{OCH}_{2} \mathrm{CH}_{2}\right), 1.0(\mathrm{t}, 3 \mathrm{H}$, $\left.\mathrm{OCH}_{2} \mathrm{CH}_{2} \underline{\mathrm{C}}_{3}\right) ;{ }^{13} \mathrm{C}-\mathrm{NMR} \delta 163(\mathrm{C}=\mathrm{O}), 152(\mathrm{HC}=), 152,112,101(\mathrm{Ph}), 116(\mathrm{CN}), 102(\mathrm{C}=), 67\left(\mathrm{OCH}_{2}\right), 22$ $\left(\mathrm{OCH}_{2} \mathrm{CH}_{2}\right), 11\left(\mathrm{OCH}_{2} \mathrm{CH}_{2} \mathrm{CH}_{3}\right)$; IR $\left(\mathrm{cm}^{-1}\right): 3150-2819(\mathrm{~m}, \mathrm{C}-\mathrm{H}), 2233(\mathrm{~m}, \mathrm{CN}), 1733(\mathrm{~s}, \mathrm{C}=\mathrm{O}), 1634$ (s, $\left.\mathrm{C}=\mathrm{C}\right), 1272(\mathrm{~s}$, C-O-C), 808, 736 (s, C-H out of plane). Anal. Calcd. for $\mathrm{C}_{13} \mathrm{H}_{10} \mathrm{~F}_{3} \mathrm{NO}_{4}$ : C, 58.00; H, 3.74; N, 5.20; Found: C, 57.80; H, $3.78 ; \mathrm{N}, 5.27$.

\subsubsection{Propyl 2-cyano-3-(3,4,5-trifluorophenyl)-2-propenoate}

Yield 68\%; mp 68 ${ }^{\circ} \mathrm{C},{ }^{1} \mathrm{H}-\mathrm{NMR} \delta 8.1(\mathrm{~s}, 1 \mathrm{H}, \mathrm{CH}=), 8.0-7.6(\mathrm{~m}, 2 \mathrm{H}, \mathrm{Ph}), 4.3\left(\mathrm{t}, 2 \mathrm{H}, \mathrm{OCH}_{2}\right), 1.7\left(\mathrm{~m}, 2 \mathrm{H}, \mathrm{OCH}_{2} \mathrm{C}_{2}\right), 1.0$ $\left(\mathrm{t}, 3 \mathrm{H}, \mathrm{OCH}_{2} \mathrm{CH}_{2} \mathrm{CH}_{3}\right) ;{ }^{13} \mathrm{C}-\mathrm{NMR} \delta 163(\mathrm{C}=\mathrm{O}), 154(\mathrm{HC}=), 150,130,105(\mathrm{Ph}), 116(\mathrm{CN}), 101(\mathrm{C}=), 67\left(\mathrm{OCH}_{2}\right), 22$ $\left(\mathrm{OCH}_{2} \underline{\mathrm{CH}}_{2}\right), 10\left(\mathrm{OCH}_{2} \mathrm{CH}_{2} \mathrm{CH}_{3}\right)$; IR $\left(\mathrm{cm}^{-1}\right): 3156-2740(\mathrm{~m}, \mathrm{C}-\mathrm{H}), 2232(\mathrm{~m}, \mathrm{CN}), 1725(\mathrm{~s}, \mathrm{C}=\mathrm{O}), 1542(\mathrm{~s}, \mathrm{C}=\mathrm{C}), 1286(\mathrm{~s}$, C-O-C), 810, 791 (s, C-H out of plane). Anal. Calcd. for $\mathrm{C}_{13} \mathrm{H}_{10} \mathrm{~F}_{3} \mathrm{NO}_{2}$ : C, 58.00; H, 3.74; N, 5.20; Found: C, 56.79; H, $3.82 ; \mathrm{N}, 5.30$.

\subsection{Copolymerization}

Copolymers of the ST and the PCPP monomers were prepared (Scheme 2) in 25-mL glass screw cap vials at ST/PCPP = 3 (mol) the monomer feed using $0.12 \mathrm{~mol} / \mathrm{L}$ of $\mathrm{ABCN}$ at an overall monomer concentration $2.44 \mathrm{~mol} / \mathrm{L}$ in $10 \mathrm{~mL}$ of toluene. The copolymerization was conducted at $70^{\circ} \mathrm{C}$. After a predetermined time, the mixture was cooled to room temperature, and precipitated dropwise in methanol. The conversion of the copolymers was kept between 10 and $20 \%$ to minimize compositional drift (Table 1). The composition of the copolymers was determined based on the nitrogen content. Since PCPP monomers do not homopolymerize, the most likely structure of the copolymers would be isolated PCPP monomer units alternating with short ST sequences (Scheme 2).

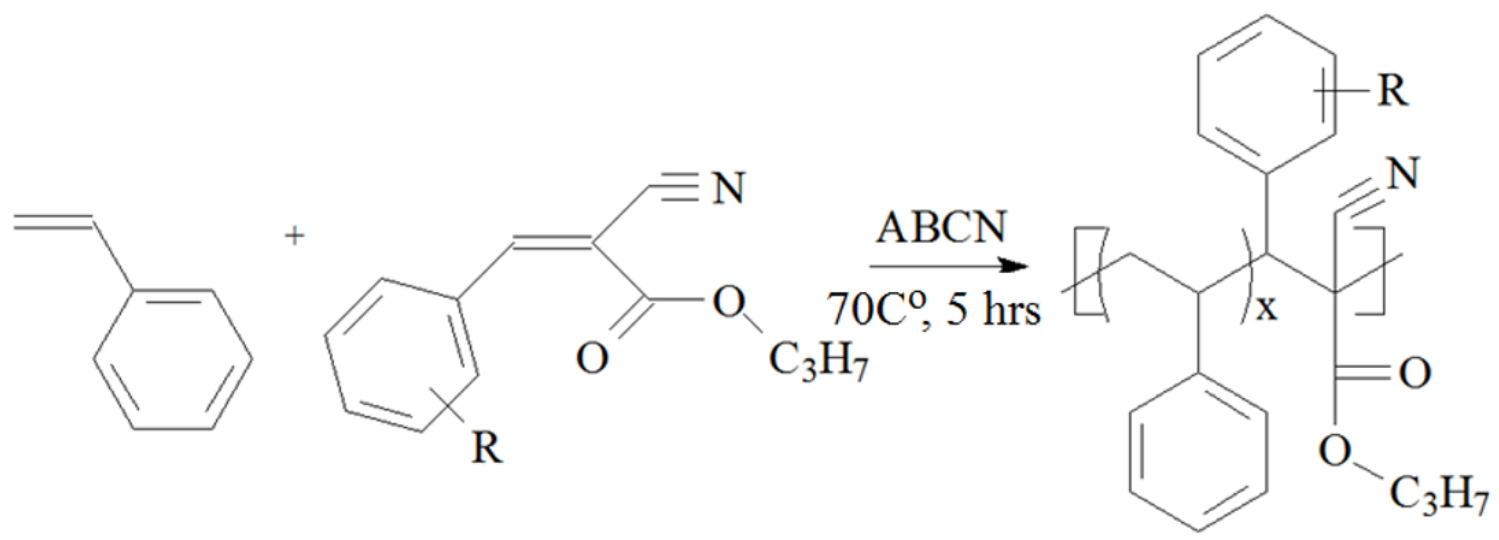

Scheme 2. ST-PCPP copolymer synthesis, $\mathrm{R}=$ 2,3,6-trichloro, 2,3,4-trifluoro, 2,3,5-trifluoro, 2,4,5-trifluoro, 2,4,6-trifluoro, 3,4,5-trifluoro

Copolymerization of ST and the ring-trisubstituted PCPP resulted in formation of copolymers (Table 1) with weight-average molecular masses 15.1 to $27.8 \mathrm{kD}$. According to elemental analysis, between 18.9 and $28.3 \mathrm{~mol} \%$ of TSE monomer is present in the copolymers prepared at ST/PCPP $=3(\mathrm{~mol})$, which is indicative of relatively high reactivity of the monomers towards ST. 
Table 1. Copolymerization of Styrene and ring-trisubstituted propyl 2-cyano-3-phenyl-2-propenoates, $\mathrm{RPhCH}=\mathrm{C}(\mathrm{CN}) \mathrm{CO}_{2} \mathrm{C}_{3} \mathrm{H}_{7}\left[\mathrm{M}_{2}\right]$.

\begin{tabular}{|c|c|c|c|c|c|c|c|c|c|c|}
\hline $\mathrm{R}$ & $\begin{array}{l}\text { Yield } \\
\text { (wt\%) }\end{array}$ & $\begin{array}{c}\mathrm{N} \\
(\mathrm{wt} \%)\end{array}$ & $\begin{array}{c}\mathrm{m}_{2} \text { in } \\
\text { copol. } \\
(\mathrm{mol} \%)\end{array}$ & $1 / r_{1}$ & $\begin{array}{c}\mathrm{M}_{\mathrm{W}} \\
(\mathrm{kD})\end{array}$ & $\begin{array}{c}\mathrm{T}_{\mathrm{g}} \\
\left({ }^{\circ} \mathrm{C}\right)\end{array}$ & $\begin{array}{c}\text { Onset of } \\
\text { decomp. } \\
\left({ }^{\circ} \mathrm{C}\right)\end{array}$ & $\begin{array}{c}10 \mathrm{wt} \% \\
\text { loss } \\
\left({ }^{\circ} \mathrm{C}\right)\end{array}$ & $\begin{array}{l}50 \text { wt } \% \\
\text { loss }\left({ }^{\circ} \mathrm{C}\right)\end{array}$ & $\begin{array}{l}\text { Residue } \\
\text { wt } \%\end{array}$ \\
\hline 2,3,6-Trichloro & 12.7 & 1.83 & 18.9 & 0.91 & 27.8 & 112 & 198 & 297 & 337 & 5.26 \\
\hline 2,3,4-Trifluoro & 14.5 & 2.17 & 21.7 & 1.15 & 15.1 & 115 & 211 & 211 & 340 & 7.10 \\
\hline 2,3,5-Trifluoro & 11.6 & 2.56 & 27.2 & 1.79 & 24.0 & 129 & 213 & 267 & 344 & 3.72 \\
\hline 2,4,5-Trifluoro & 12.8 & 2.60 & 27.8 & 1.89 & 20.6 & 123 & 194 & 279 & 338 & 6.12 \\
\hline 2,4,6-Trifluoro & 14.4 & 2.63 & 27.8 & 1.89 & 21.9 & 122 & 193 & 257 & 253 & 5.50 \\
\hline 3,4,5-Trifluoro & 15.2 & 1.39 & 28.3 & 1.96 & 19.1 & 127 & 212 & 229 & 259 & 5.75 \\
\hline
\end{tabular}

In an attempt to qualitatively correlate the observed monomer reactivities, we considered copolymer composition data. The relative reactivity of ST in copolymerization with these monomers can be estimated by assuming applicability of the copolymerization equation (Eq. 1) of the terminal copolymerization model (Odian 2004):

$$
m_{1} / m_{2}=\left[\mathrm{M}_{1}\right]\left(r_{1}\left[\mathrm{M}_{1}\right]+\left[\mathrm{M}_{2}\right]\right) /\left[\mathrm{M}_{2}\right]\left(\left[\mathrm{M}_{1}\right]+r_{2}\left[\mathrm{M}_{2}\right]\right)
$$

$m_{1}$ and $m_{2}$ are the mole fractions of ST and PCPP monomer units in the copolymer, respectively, $\left[\mathrm{M}_{1}\right]$ and $\left[\mathrm{M}_{2}\right]$ are the concentrations of ST and a PCPP in the monomer feed, respectively. The monomer reactivity ratios, $r_{1}$ and $r_{2}$ are $k_{11} / \mathrm{k}_{12}$ and $k_{22} / \mathrm{k}_{21}$, respectively. In the absence of the self-propagation of PCPP monomers $\left(k_{22}=0, r_{2}=0\right)$, and at the monomer feed $\left(\left[\mathrm{M}_{1}\right] /\left[\mathrm{M}_{2}\right]=3\right)$, the above equation yields:

$$
r_{1}=\left(m_{1} / m_{2}-1\right) / 3
$$

or the equation for the relative reactivity of styrene radical $k_{12} / k_{11}$ with PCPP monomers

$$
1 / r_{1}=3 /\left(m_{1} / m_{2}\right)-1
$$

Consideration of monomer reactivities according to Equation 3 also involves the assumption of minimal copolymer compositional drift at given conversion. This non-rigorous kinetic treatment (Odian, 2004) allows estimation of the reactivity of a ST-ended polymer radical in reaction with PCPP monomer (Table 1).

\subsection{Structure and Thermal Properties}

The structure of ST-PCPP copolymers was characterized by IR and NMR spectroscopy. A comparison of the spectra of the monomers, copolymers and polystyrene shows, that the reaction between the TSE monomers and ST is a copolymerization. IR spectra of the copolymers show overlapping bands in $3200-2820 \mathrm{~cm}^{-1}$ region corresponding to $\mathrm{C}-\mathrm{H}$ stretch vibrations. The bands for the PCPP monomer unit are 2240-2234 (w, CN), 1745-1730 (s, C=O), and $1250-1220 \mathrm{~cm}^{-1}$ (m, C-O). Benzene rings of both monomers show ring stretching bands at $1500-1400 \mathrm{~cm}^{-1}$ as well as a doublet $826-715 \mathrm{~cm}^{-1}$, associated with $\mathrm{C}-\mathrm{H}$ out of plane deformations. These bands can be readily identified in styrene copolymers with TSE monomers containing cyano and carbonyl electron withdrawing groups.

The ${ }^{1} \mathrm{H}-\mathrm{NMR}$ spectra of the ST-PCPP copolymers show a broad double peak in a 6.0-8.0 ppm region corresponding to phenyl ring protons. A resonance at 4.4-3.6 ppm is assigned to the methyleneoxy protons of PCPP monomer unit. A broad resonance at 3.0-2.0 ppm is assigned to the methyl and methine protons of PCPP, and methine and methylene protons of ST monomer unit close to the propenoate unit, which are more subjected to deshielding than the ones in polystyrene. The low and high field components of the signal are associated with PCPP monomer unit in head-to-tail and head-to-head structures (Kharas, Murau, Watson, \& Harwood, 1992). A broad resonance peak in 0.9-2.3 ppm range is attributed to the methine and methylene protons of styrene monomer sequences, as well as to alkyl ester protons of PCPP. The ${ }^{13} \mathrm{C}$-NMR spectra also support the suggested skeletal structure of the copolymers. Thus, the assignment of the peaks is as follows: 164-160 ppm $(\mathrm{C}=\mathrm{O}), 156-130 \mathrm{ppm}$ (quaternary carbons of both phenyls), 145-120 ppm (phenyl carbons), 118-112 ppm (CN), 60-50 ppm (methine and quaternary carbons PCPP carbons), 47-45 ppm (ST methine), and 44-40 ppm (ST methylene), 36-10 ppm alkyl carbons of PCPP. Broadening of the NMR signals in the spectra of the copolymers is apparently associated with head-to-tail and head-to-head structures, which formed though the attack of a styrene-ended radical on both sides of TSE monomer (Kharas et al, 1992). The IR and NMR data showed that these are true copolymers, composed of both TSE and ST monomer units.

The copolymers prepared in the present work are all soluble in ethyl acetate, THF, DMF and $\mathrm{CHCl}_{3}$ and insoluble in methanol, ethyl ether, and petroleum ether. They are amorphous and show no crystalline DSC endotherm. Results of 
thermal analysis of ST-PCPP copolymers are presented in Table 1. Information on the degradation of the copolymers was obtained from thermogravimetric analysis. Decomposition of the copolymers in nitrogen occurred in two steps, first in the $190-500^{\circ} \mathrm{C}$ range with residue (3.7 -7.1\% wt.), which then decomposed in the $500-800^{\circ} \mathrm{C}$ range. The decomposition products were not analyzed in this study, and the mechanism has yet to be investigated.

\section{Conclusions}

Novel trisubstituted ethylenes, ring-trisubstituted propyl 2-cyano-3-phenyl-2-propenoates $\mathrm{RPhCH}=\mathrm{C}(\mathrm{CN}) \mathrm{CO}_{2} \mathrm{C}_{3} \mathrm{H}_{7}$ (where $\mathrm{R}$ is 2,3,6-trichloro, 2,3,4-trifluoro, 2,3,5-trifluoro, 2,4,5-trifluoro, 2,4,6-trifluoro, 3,4,5-trifluoro) were prepared and copolymerized with styrene. The compositions of the copolymers were calculated from nitrogen analysis and the structures were analyzed by IR, $\mathrm{H}^{1}$ and ${ }^{13} \mathrm{C}-\mathrm{NMR}$. The thermal gravimetric analysis indicated that the copolymers decompose in in two steps, first in the $190-500^{\circ} \mathrm{C}$ range with residue $(3.7-7.1 \%$ wt), which then decomposed in the $500-800^{\circ} \mathrm{C}$ range.

\section{References}

Caggiano, T. J., Brazzale, A., Ho, D. M., Kraml, C. M., Trybulski, E., Chadwick, C. C., ... Keith, J. C. (2007). Estrogen receptor dependent inhibitors of NF- $\mathrm{BB}$ transcriptional activation-1 synthesis and biological evaluation of substituted 2-cyanopropanoic acid derivatives: Pathway selective inhibitors of NF- $\mathrm{KB}$, a potential treatment for rheumatoid arthritis. J. Medicinal Chem., 50, 5245-5248. https://doi.org/10.1021/jm701013k

Hall, H. K. Jr., \& Daly, R. C. (1975). Electron-deficient trisubstituted olefins. A new class of reactive monomers. Macromolecules, 8, 22-29. https://doi.org/10.1021/ma60043a006

Hall, H. K., Jr. \& Ykman, P. (1977). Trisubstituted ethylenes containing halo, cyano, and carbomethoxy substituents. New reactive comonomers. Macromolecules, 10, 464-469. https://doi.org/10.1021/ma60056a044

Hall, H. K., Jr., \& Padias, A. B. (2004). Organic and polymer chemistry of electrophilic tri- and tetrasubstituted ethylenes. J. Polym. Sci.Part A: Polym. Chem., 42, 2845-2858. https://doi.org/10.1002/pola.20190

Kharas, G. B. (1996). Trisubstituted ethylene copolymers. In J. C. Salamone (Ed.), Polymeric Materials Encyclopedia (Vol. 11, 8405-8409). Boca Raton, FL, USA: CRC Press.

Kharas, G. B., Hanawa, E., Hill, B. L., Flynn, K., Husain, H., Mbatchou, J. W., ... Raihane, M. (2011). Novel copolymers of 4-fluorostyrene. 8. Some ring-trisubstituted 2-phenyl-1,1-dicyanoethylenes. J. Macromol. Sci. A48, 327-331. https://doi.org/10.1080/10601325.2011.562456

Kharas, G. B., Murau, P. A., Watson, K., \& Harwood, H. J. (1992). Microstructure of styrene copolymers with 2-phenyl-1,1-cyanoethene. Polymer International, 28, 67-74. https://doi.org/10.1002/pi.4990280112

Kharas, G. B., Rocus, S. M., Locke, M. C., Macke, W. J., Oh, S. S., Pagan, N. A., ... Weingart, J. (2016). Novel copolymers of styrene. 14. Halogen ring-trisubstituted butyl 2-cyano-3-phenyl-2-propenoates. J. Macromol. Sci. A53, 465-469. https://doi.org/10.1080/10601325.2016.1189278

Matsuoka, M., Takao, M., Kitao, T., Fujiwara, T., \& Nakatsu, K. (1990). Cyanovinylheteroaromatics for organic nonlinear optics. Molecular Crystals and Liquid Crystals, 182A, 71-79. https://doi.org/10.1080/00268949008047789

Odian, G. (2004). Principles of Polymerization (4th Ed.) New York, NY:Wiley-Interscience. https://doi.org/10.1002/047147875X

Sidhu, A., Sharma, J. R., \& Rai, M. (2008). Antifungal potential of ethyl benzalcyanoacetate and its C-phenyl derivatives J. Mycology and Plant Pathology, 38, 341-343.

Smith, M. B., \& March, J. (2001). Addition to Carbon-Hetero Multiple Bonds, In March's Advanced Organic Chemistry, New York, NY:Wiley \& Sons.

Tiwari, S., Gupta, S., Tripathi, R. P., Khan, A. R., Katiyar, J. C., \& Bhaduri, A. P. (1999). Synthesis and antileishmanial activity of ethyl $\alpha$-cyanopropenoates. A new class of antileishmanials Arzneimittel-Forschung, 49, 144-148.

\section{Copyrights}

Copyright for this article is retained by the author(s), with first publication rights granted to the journal.

This is an open-access article distributed under the terms and conditions of the Creative Commons Attribution license (http://creativecommons.org/licenses/by/4.0/). 